\title{
Identification of a Prophage-encoded Abortive Infection System in Levilactobacillus brevis
}

\author{
Marine Feyereisen ${ }^{1}$, Jennifer Mahony ${ }^{1,2}$, Tadhg O'Sullivan ${ }^{3}$, Viktor Boer ${ }^{3}$, and Douwe van Sinderen ${ }^{1,2 *}$ \\ ${ }^{1}$ School of Microbiology, University College Cork, T12 YT20 Cork, Ireland \\ ${ }^{2}$ APC Microbiome Ireland, University College Cork, T12 YT20 Cork, Ireland \\ ${ }^{3}$ HEINEKEN Global Innovation and Research, Heineken Supply Chain B.V, 2382 PH, Zoeterwoude, The Netherlands
}

Received: February 25, 2020 / Revised: April 10, 2020 / Accepted: April 24, 2020

\begin{abstract}
Abortive infection systems (Abi) are phage resistance systems that can be prophage-encoded. Here, two genes encoding an Abi system were identified on a prophage sequence contained by the chromosome of the Levilactobacillus brevis strain UCCLBBS124. This Abi system is similar to the two-component AbiL system encoded by Lactococcus lactis biovar. diacetylactis LD10-1. The UCCLBBS124 prophage-derived Abi system (designated here as $\mathrm{AbiL}_{124}$ ) was shown to exhibit specific activity against phages infecting $L$. brevis and $L$. lactis strains. Expression of the $\mathrm{AbiL}_{124}$ system was shown to cause reduction in the efficiency of plaquing and cell lysis delay for phages of both species.
\end{abstract}

Keywords: Abi system, bacteriophage, lactic acid bacteria, beer spoilage

Lactobacillus brevis, recently reclassified as Levilactobacillus brevis REFERENCE: PMID: 32293557 , belongs to the lactic acid bacteria (LAB), food and fermentation industry [1]; however, it is also associated with the spoilage of beer. There is an ever-increasing consumer demand for natural food preservation methods, and in this context, bacteriophages possess the potential to control such spoilage microorganisms [2, 3]. Virulent phages active against $L$. brevis have been isolated and characterized, revealing a narrow host range $[4,5]$ and suggesting the presence of resistance mechanisms against these bacteriophages. Various naturally occurring, phage-derived defence systems against LAB phages have been identified, including abortive infection (Abi) systems [6-9]. Abi systems block phage multiplication leading to the release of few (if any) infective virions and cause death of infected cells, thereby protecting the overall bacterial population [10]. More specifically, Abi

\section{*Corresponding author}

Tel: +353 214901365

E-mail: d.vansinderen@ucc.ie

○ 2020, The Korean Society for Microbiology and Biotechnology systems interfere with phage development following phage adsorption and DNA injection into the host, resulting in an absence of plaques or a reduction in plaque size coupled with significant cell death [11-14]. Many Abi systems are encoded by a single gene, though two-component Abi systems have also been identified [8]. A notable feature among Abi systems is the high $\mathrm{A}+\mathrm{T}$ content (usually $70 \%$ ) of the genes encoding these systems [15]. Studies focused on phage-resistance systems in lactobacilli are very limited and just a single, plasmid-encoded phage-resistance system has been described for Lactobacillus plantarum NGRI0101 plasmid pLKS [16]. In the present study, analysis of $L$. brevis prophages revealed the presence of a potential prophage-encoded Abi system located within the chromosome of a beer-spoiling L. brevis strain. This Abi system was shown to be functional and is encoded by two genes, with sequence similarity to the previously characterized lactococcal AbiL system [8].

Predicted prophage regions were identified on the chromosome of nineteen $L$. brevis strains using PHASTER. Among these predicted prophage regions a 


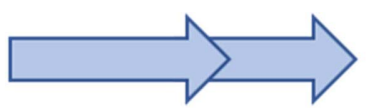

$\begin{array}{ll}\text { UCCLBBS124_1418 } & \begin{array}{l}\text { UCCLBBS124_1417 } \\ =a b i L i_{124}\end{array} \\ =a b i L i i_{124} \\ 1230 \mathrm{nt} & 609 \mathrm{nt}\end{array}$

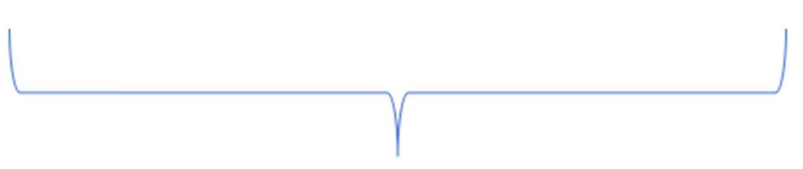

$$
\operatorname{abiL}_{124}
$$

Fig. 1. Genetic organization of the AbiL ${ }_{124}$ system.

BlastP analysis revealed the presence of an identical putative abi system carried by three prophage regions located on the chromosome of $L$. brevis strains UCCLBBS124, NPS-QW-145 and SRCM101174. This putative $a b i$ system is composed of two genes with a $\mathrm{A}+\mathrm{T}$ content of $68 \%$ similar to that observed for other abi genes [15]. The proteins encoded by this putative $a b i$ system display similarity (approximately 35\% at amino acid level; data not shown) to the two proteins of the AbiL system previously identified in L. lactis [8]. Of these three $L$. brevis strains, only $L$. brevis strain UCCLBBS124 was available in our collection for further characterization of this putative Abi system encoded by its temperate phage TPMB124. The putative abi system carried by prophage TPMB124, designated here as $a b i L_{124}$, is composed of two genes which appear to be organized as an operon due to their apparent translational coupling as had previously been observed for the lactococcal AbiL system (Fig. 1) [8].

To assess the effect of $\mathrm{AbiL}_{124}$ on the phage sensitivity profile of different host bacteria, the genes encoding $\mathrm{AbiL}_{124}$ were cloned into pNZ44 to generate plasmid
pNZ44:abiL ${ }_{124}$, which was then introduced into $L$. brevis strains UCCLB521 and SA-C12. In the case of UCCLB521 pNZ44:abiL 124 significant phage resistance was observed against phages $3-521,521 \mathrm{~B}$ and SAC12B with an EOP (Efficiency of plaquing) that was lower than $10^{-8}$ (Table 1), demonstrating the functionality and efficacy of this prophage-encoded phage resistance system. Conversely, no such resistance was observed for SA-C12 and its derivative expressing the putative Abi system, SA-C12 pNZ44:abiL 124 against phages 3-SAC12 and SAC12B (Table 1). The role of the individual genes constituting $a b i L_{124}$ in conferring phage resistance to UCCLB521 was also investigated. After introduction of the individual genes separately in UCCLB521, no resistance to phages was observed (data not shown) confirming the requirement for both genes for an active $\mathrm{AbiL}_{124}$ phage resistance system. Lysis-in-broth and cell death experiments were conducted to study the effect of the $\mathrm{AbiL}_{124}$ system on actively growing cells. Expression of $\mathrm{AbiL}_{124}$ in $L$. brevis UCCLB521 allowed significantly improved survival after phage infection relative to the wild-type and the strain carrying an empty plasmid pNZ44 as shown by lysis-in-broth experiments (Fig. 2). The strain expressing the $\mathrm{AbiL}_{124}$ system exhibits growth in the presence of phages $3-521$ or $521 \mathrm{~B}$, yet the level of growth is significantly lower than that observed for the strain in the absence of either of these phages (Fig. 2). Cell death was calculated following phage infection of the L. brevis strain in broth for $30 \mathrm{~h}$, which indicated that approximately 64 and $60 \%$ of the cells of UCCLB521 expressing the $\mathrm{AbiL}_{124}$ system lost viability following infection with phages 3-521 and 521B, respectively (Table 2). Adsorption assays revealed a significant lower adsorption efficiency of phages 3-521 and 521B on L. brevis strain UCCLB521 expressing the $\mathrm{AbiL}_{124}$ sys-

Table 1. Efficiency of plaquing of tested bacteriophages against the putative L. brevis AbiL 124 $_{\text {System. }}$

\begin{tabular}{|c|c|c|c|c|c|c|c|}
\hline & & \multicolumn{6}{|c|}{ Lb. brevis strains } \\
\hline & & \multicolumn{3}{|c|}{ UCCLB521 } & \multicolumn{3}{|c|}{ SA-C12 } \\
\hline & & WT & pNZ44 & pNZ44:abiL 124 & WT & pNZ44 & $\mathrm{pNZ44} a_{b i L_{124}}$ \\
\hline \multirow{4}{*}{ Phage } & 3-521 (Group I) & 1 & 0.58 & $<10^{-8}$ & $N / A^{a}$ & $\mathrm{~N} / \mathrm{A}$ & $\mathrm{N} / \mathrm{A}$ \\
\hline & 521B (Group I) & 1 & 1.52 & $<10^{-8}$ & N/A & N/A & N/A \\
\hline & SAC12B (Group I) & 1 & 0.98 & $<10^{-8}$ & 1 & 0.97 & 0.90 \\
\hline & 3-SAC12 (Group II) & $\mathrm{N} / \mathrm{A}$ & $\mathrm{N} / \mathrm{A}$ & $\mathrm{N} / \mathrm{A}$ & 1 & 0.96 & 0.94 \\
\hline
\end{tabular}

${ }^{\mathrm{a}} \mathrm{N} / \mathrm{A}$ : not applicable 


\section{UCCLB521}

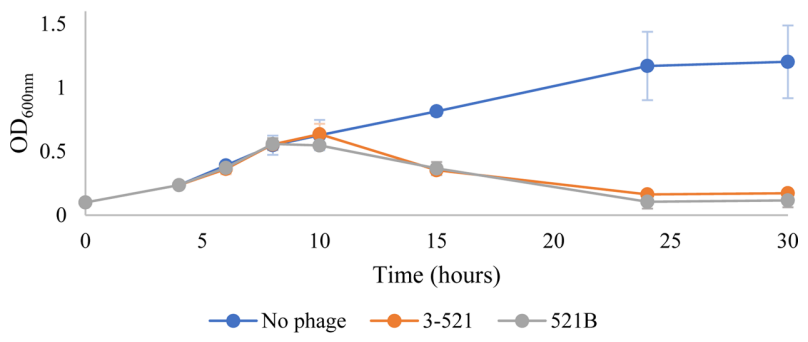

UCCLB521 pNZ44

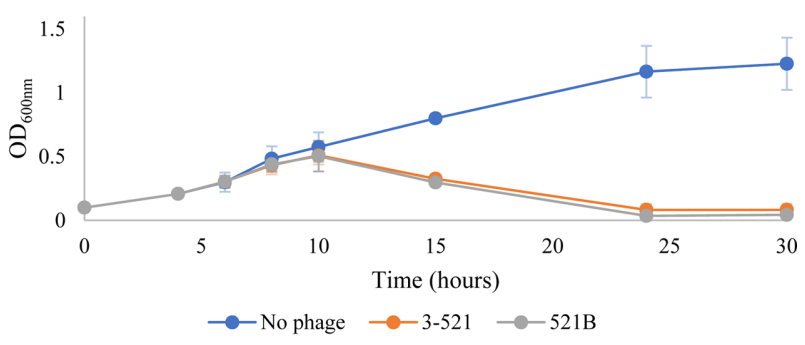

UCCLB521 pNZ44:abiL $L_{124}$

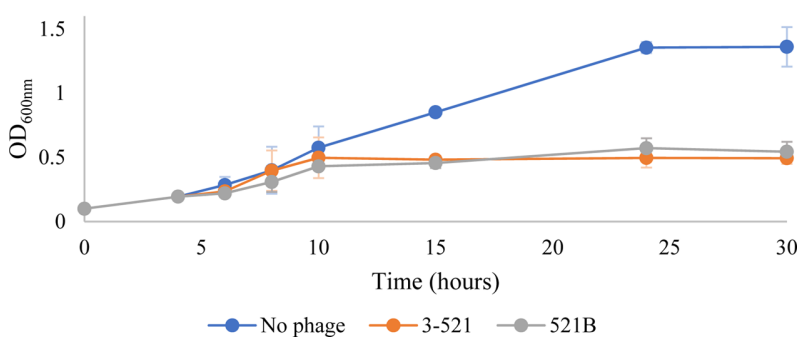

Fig. 2. Lysis-in-broth experiments comparing the lysis profiles of UCCLB521 WT, harboring the empty vector pNZ44 or expressing the $\mathrm{AbiL}_{124}$ system when infected with phages 3-521 (orange) or 521B (grey) $(\mathrm{MOI}=1)$. Absence of phage in the culture was used as a negative control (blue).

tem with an adsorption efficiency 2.5 (for phage 521B) to 4 (for phage 3-521) times lower than that observed for the WT sensitive strain (Table 2). These observations are unusual for an Abi system as Abi systems predominantly act intracellularly by interfering with phage development following phage adsorption and DNA injection [8]. To determine if phage-infected strains released viable phages, ECOI (Efficiency of the Center Of Infection) experiments were performed demonstrating the significant inability of the strain expressing the $\mathrm{AbiL}_{124}$ system (UCCLB521 pNZ44:abiL 124 ) to produce viable phages (Table 2). AbiL ${ }_{124}$ was shown to provide complete phage resistance for one strain of $L$. brevis and its activity was also tested on $L$. lactis strains. The $a b i L_{124}$ genes were expressed in L. lactis NZ9000 and 3107 and tested for their effectiveness against a range of phages (Table 3). AbiL $\mathrm{A}_{124}$ was shown to confer almost complete resis-

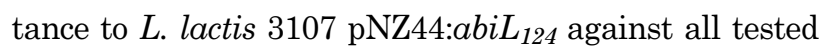
phages with EOPs lower than $10^{-9}$. The $\mathrm{AbiL}_{124}$ system was shown to be active against phages belonging to different phage groups (936, 949, P335 and P087 groups), thus showing a broad activity-range against lactococcal phages. Phage resistance was also observed in $L$. lactis NZ9000 carrying the $a b i L_{124}$ genes but not to the same extent (Table 3) as in 3107. Significant $(p<0.05)$ resistance against phages jj50, p2 and sk1 were observed for NZ9000 expressing the $\mathrm{AbiL}_{124}$ system, however no significant difference was observed against phage 712 which remained active in infection of the derivative strain (Table 3).

In this study, a novel Abi system was identified on prophage regions of three L. brevis strains. This Abi system comprises two translationally coupled ORFs, both required for conferring phage resistance to the host. Consequences of this $\mathrm{AbiL}_{124}$ system on targeted phages are elimination of their efficiency of plaquing, a reduction in their adsorption efficiency and a significant

Table 2. Phenotypic characteristics of the potential $\mathrm{AbiL}_{124}$ system.

\begin{tabular}{|c|c|c|c|c|}
\hline L. brevis strains & Phage & Cell death (\%) & Adsorption (\%) & $\mathrm{ECOI}^{\mathrm{a}}$ \\
\hline \multirow[t]{2}{*}{ UCCLB521 WT } & $3-521$ & 100 & $95.9 \pm 2.6$ & 1 \\
\hline & $521 \mathrm{~B}$ & 100 & $96.1 \pm 2.5$ & 1 \\
\hline \multirow[t]{2}{*}{ UCCLB521 pNZ44 } & $3-521$ & $99.2 \pm 2.3$ & $86.7 \pm 1.7$ & $0.92 \pm 0.27$ \\
\hline & $521 B$ & $98.7 \pm 1.3$ & $94.4 \pm 1.2$ & $0.97 \pm 0.03$ \\
\hline \multirow[t]{2}{*}{ UCCLB521 pNZ44:abil 124} & $3-521$ & $64.1 \pm 0.9$ & $22.7 \pm 4.7$ & 0 \\
\hline & $521 B$ & $60.2 \pm 0.7$ & $37.1 \pm 5.6$ & $0.04 \pm 0.03$ \\
\hline
\end{tabular}

${ }^{a}$ ECOI: Efficiency of the center of infection 
Table 3. Efficiency of plaquing of tested lactococcal bacteriophages against the putative L. brevis AbiL 124 $_{\text {System (results are }}$ average of triplicate assays).

\begin{tabular}{|c|c|c|c|c|c|c|c|}
\hline & & \multicolumn{6}{|c|}{ L. lactis strains } \\
\hline & & \multicolumn{3}{|c|}{3107} & \multicolumn{3}{|c|}{ NZ9000 } \\
\hline & & WT & pNZ44 & pNZ44:abiL ${ }_{124}$ & WT & pNZ44 & pNZ44:abiL ${ }_{124}$ \\
\hline \multirow{12}{*}{$\begin{array}{c}\text { Phage } \\
\text { (phage group) }\end{array}$} & TP901-1 (P335) & 1 & 0.66 & $<10^{-11}$ & $\mathrm{~N} / \mathrm{A}^{\mathrm{a}}$ & $\mathrm{N} / \mathrm{A}$ & $\mathrm{N} / \mathrm{A}$ \\
\hline & LC3 (P335) & 1 & 0.75 & $<10^{-11}$ & N/A & $\mathrm{N} / \mathrm{A}$ & $\mathrm{N} / \mathrm{A}$ \\
\hline & Dub35A (P335) & 1 & 1 & $<10^{-12}$ & $\mathrm{~N} / \mathrm{A}$ & $\mathrm{N} / \mathrm{A}$ & $\mathrm{N} / \mathrm{A}$ \\
\hline & $62601(936)$ & 1 & 1 & $<10^{-12}$ & $\mathrm{~N} / \mathrm{A}$ & $\mathrm{N} / \mathrm{A}$ & N/A \\
\hline & 66901 (936) & 1 & 1.57 & $<10^{-10}$ & $\mathrm{~N} / \mathrm{A}$ & $\mathrm{N} / \mathrm{A}$ & $\mathrm{N} / \mathrm{A}$ \\
\hline & 949 (949) & 1 & 0.96 & $<10^{-10}$ & $\mathrm{~N} / \mathrm{A}$ & $\mathrm{N} / \mathrm{A}$ & $\mathrm{N} / \mathrm{A}$ \\
\hline & WRP3 (949) & 1 & 0.83 & $6.1 \times 10^{-7}$ & $\mathrm{~N} / \mathrm{A}$ & $\mathrm{N} / \mathrm{A}$ & $\mathrm{N} / \mathrm{A}$ \\
\hline & P087 (P087) & 1 & 0.86 & $<10^{-9}$ & $\mathrm{~N} / \mathrm{A}$ & $\mathrm{N} / \mathrm{A}$ & $\mathrm{N} / \mathrm{A}$ \\
\hline & jj50 (936) & N/A & $\mathrm{N} / \mathrm{A}$ & $\mathrm{N} / \mathrm{A}$ & 1 & 1 & 0.70 \\
\hline & p2 (936) & N/A & $\mathrm{N} / \mathrm{A}$ & $\mathrm{N} / \mathrm{A}$ & 1 & 1.09 & 0.71 \\
\hline & sk1 (936) & N/A & $\mathrm{N} / \mathrm{A}$ & $\mathrm{N} / \mathrm{A}$ & 1 & 0.96 & 0.71 \\
\hline & 712 (936) & N/A & $\mathrm{N} / \mathrm{A}$ & $\mathrm{N} / \mathrm{A}$ & 1 & 1.12 & 1.02 \\
\hline
\end{tabular}

${ }^{\mathrm{a}} \mathrm{N} / \mathrm{A}$ : not applicable

decline in the number of progeny phage released. Interestingly, the Abi system identified in this study on $L b$. brevis prophages was shown to be active against phages infecting $L$. lactis strains revealing a broad activity range. This Abi system only shows sequence similarity to the already described AbiL system [8] even though the $\mathrm{AbiL}_{124}$ system showed to be active against lactococcal phages of the P335 group unlike the AbiL system. The phage resistance system described here shows similarities and impacts on phage/host interaction that are consistent with other Abi systems. However, further experiments are needed to elucidate if this phage resistance mechanism is due to the inability of the phage to penetrate the host (low adsorption efficiency) or to exit the host once inside (e.g. due to DNA replication inhibition as observed for AbiA [12] or due to phage protein synthesis inhibition as described for AbiL [8]). The findings presented here reveal new insights into phage resistance mechanisms in $L$. brevis strains and the benefits conferred by their resident prophages. Considering the negative impact of $L$. brevis strains on beer spoilage and the increased demand in bioremediation process during the fermentation process, it is important to understand natural phage defence systems in order to develop effective phage-based treatments to eliminate bacterial beer spoilage.

\section{Acknowledgments}

Marine Feyereisen is the recipient of an Irish Research Council Enterprise Partnership Scheme postgraduate scholarship (Ref. No. EPSPG/ 2015/7). Douwe van Sinderen is supported by a Principal Investigator award (Ref. No. 450 13/IA/1953) through Science Foundation Ireland (SFI). Jennifer Mahony is in receipt of Starting Investigator Research Grant (SIRG) (Ref. No. 15/SIRG/3430) funded by Science Foundation Ireland (SFI).

\section{Conflict of Interest}

The authors have no financial conflicts of interest to declare.

\section{References}

1. Meignen B, Onno B, Gélinas $P$, Infantes $M$, Guilois $S$, Cahagnier B. 2001. Optimization of sourdough fermentation with Lactobacillus brevis and baker's yeast. Food Microbiol. 18: 239-245.

2. Endersen L, O'Mahony J, Hill C, Ross RP, McAuliffe O, Coffey A. 2014. Phage therapy in the food industry. Ann. Rev. Food Sci. Technol. 5: 327-349.

3. Mahony J, McAuliffe O, Ross RP, van Sinderen D. 2011. Bacteriophages as biocontrol agents of food pathogens. Curr. Opin. Biotechnol. 22: 157-163.

4. Deasy T, Mahony J, Neve H, Heller KJ, van Sinderen D. 2011. Isolation of a virulent Lactobacillus brevis phage and its application in the control of beer spoilage. J. Food Prot. 74: 2157-2161.

5. Feyereisen M, Mahony J, Lugli GA, Ventura M, Neve H, Franz 
CMAP, et al. 2019. Isolation and characterization of Lactobacillus brevis phages. Viruses 11: 393.

6. Mahony J, McGrath S, Fitzgerald GF, van Sinderen D. 2008. Identification and characterization of lactococcal-prophage-carried superinfection exclusion genes. Appl. Environ. Microbiol. 74: 6206-6215.

7. Kelleher P, Mahony J, Schweinlin K, Neve H, Franz C, van Sinderen D. 2018. Assessing the functionality and genetic diversity of lactococcal prophages. Int. J. Food Microbiol. 272: 29-40.

8. Deng YM, Liu CQ, Dunn NW. 1999. Genetic organization and functional analysis of a novel phage abortive infection system, AbiL, from Lactococcus lactis. J. Biotechnol. 67: 135-149.

9. McGrath S, Fitzgerald GF, van Sinderen D. 2002. Identification and characterization of phage-resistance genes in temperate lactococcal bacteriophages. Mol. Microbiol. 43: 509-520.

10. Chopin M-C, Chopin A, Bidnenko E. 2005. Phage abortive infection in lactococci: variations on a theme. Curr. Opin. Microbiol. 8 : 473-479.

11. Hill C. 1993. Bacteriophage and bacteriophage resistance in lactic acid bacteria. FEMS Microbiol. Rev. 12: 87-108.

12. Moineau S, Durmaz E, Pandian S, Klaenhammer TR. 1993. Differentiation of two abortive mechanisms by using monoclonal antibodies directed toward lactococcal bacteriophage capsid proteins. Appl. Environ. Microbiol. 59: 208-212.

13. Garvey P, Fitzgerald GF, Hill C. 1995. Cloning and DNA sequence analysis of two abortive infection phage resistance determinants from the lactococcal plasmid pNP40. Appl. Environ. Microbiol. 61: 4321-4328.

14. Parreira R, Ehrlich SD, Chopin MC. 1996. Dramatic decay of phage transcripts in lactococcal cells carrying the abortive infection determinant AbiB. Mol. Microbiol. 19: 221-230.

15. O'Connor L, Coffey A, Daly C, Fitzgerald GF. 1996. AbiG, a genotypically novel abortive infection mechanism encoded by plasmid pCl750 of Lactococcus lactis subsp. cremoris UC653. Appl. Environ. Microbiol. 62: 3075-3082.

16. Eguchi T, Doi K, Nishiyama K, Ohmomo S, Ogata S. 2000. Characterization of a phage resistance plasmid, pLKS, of silage-making Lactobacillus plantarum NGRI0101. Biosci. Biotechnol. Biochem. 64: 751-756.

17. Feyereisen $M$, Mahony J, Kelleher $P$, Roberts RJ, O'Sullivan T, Geertman J-MA, et al. 2019. Comparative genome analysis of the Lactobacillus brevis species. BMC Genomics 20: 416.

18. Kuipers OP, de Ruyter PGGA, Kleerebezem M, de Vos WM. 1998. Quorum sensing-controlled gene expression in lactic acid bacteria. J. Biotechnol. 64: 15-21.

19. Braun Jr V, Hertwig S, Neve H, Geis A, Teuber M. 1989. Taxonomic differentiation of bacteriophages of Lactococcus lactis by electron microscopy, DNA-DNA hybridization, and protein profiles. Microbiology 135: 2551-2560.

20. Christiansen B, Johnsen M, Stenby E, Vogensen F, Hammer K. 1994. Characterization of the lactococcal temperate phage TP901-1 and its site-specific integration. J. Bacteriol. 176: 10691076.
21. Blatny JM, Godager L, Lunde M, Nes IF. 2004. Complete genome sequence of the Lactococcus lactis temperate phage $\varphi \mathrm{LC} 3$ : comparative analysis of $\varphi \mathrm{LC} 3$ and its relatives in lactococci and streptococci. Virology 318: 231-244.

22. Mahony J, Oliveira J, Collins B, Hanemaaijer L, Lugli GA, Neve H, et al. 2017. Genetic and functional characterisation of the lactococcal P335 phage-host interactions. BMC Genomics 18: 146.

23. Oliveira J, Mahony J, Hanemaaijer L, Kouwen TRHM, van Sinderen D. 2018. Biodiversity of bacteriophages infecting Lactococcus lactis starter cultures. J. Dairy Sci. 101: 96-105.

24. Theodorou I. 2019. Investigation of glycopolymer assembly systems in Lactococcus lactis. University College Cork, Ireland, cora.ucc.ie.

25. Mahony J, Deveau H, Mc Grath S, Ventura M, Canchaya C, Moineau S. 2006. Sequence and comparative genomic analysis of lactococcal bacteriophages jj50, 712 and P008: evolutionary insights into the 936 phage species. FEMS Microbiol. Lett. 261: 253-261.

26. Bebeacua C, Tremblay D, Farenc C, Chapot-Chartier M-P, Sadovskaya I, van Heel, M. et al. 2013. Structure, adsorption to host, and infection mechanism of virulent lactococcal phage p2. J. Virol. 87: 12302-12312.

27. Chandry PS, Moore SC, Boyce JD, Davidson BE, Hillier AJ. 1997. Analysis of the DNA sequence, gene expression, origin of replication and modular structure of the Lactococcus lactis lytic bacteriophage sk1. Mol. Microbiol. 26: 49-64.

28. Samson JE, Moineau S. 2010. Characterization of Lactococcus lactis phage 949 and comparison with other lactococcal phages. Appl. Environ. Microbiol. 76: 6843-6852.

29. Mahony J, Randazzo W, Neve H, Settanni L, van Sinderen D. 2015. Lactococcal 949 group phages recognize a carbohydrate receptor on the host cell surface. Appl. Environ. Microbiol. 81: 32993305.

30. Villion M, Chopin M-C, Deveau H, Ehrlich SD, Moineau S, Chopin A. 2009. P087, a lactococcal phage with a morphogenesis module similar to an Enterococcus faecalis prophage. Virology 388: 4956.

31. Svensson U, Christiansson A. 1991. Methods for phage monitoring. Bulletin of the Int. Dairy Federation 263: 29-39.

32. Zhou Y, Liang Y, Lynch KH, Dennis JJ, Wishart DS. 2011. PHAST: a fast phage search tool. Nucleic Acids Res. 39: 347-352.

33. Arndt D, Grant JR, Marcu A, Sajed T, Pon A, Liang Y, Wishart DS. 2016. PHASTER: a better, faster version of the PHAST phage search tool. Nucleic Acids Res. 44: W16-21.

34. McGrath S, Fitzgerald GF, van Sinderen D. 2001. Improvement and optimization of two engineered phage resistance mechanisms in Lactococcus lactis. Appl. Environ. Microbiol. 67: 608-616.

35. van Pijkeren J-P, Britton RA. 2012. High efficiency recombineering in lactic acid bacteria. Nucleic Acids Re. 40: e76.

36. Ahrné S, Molin G, Axelsson L. 1992.Transformation of Lactobacillus reuteri with electroporation: studies on the erythromycin resistance plasmid pLUL631. Curr. Microbiol. 24: 199-205.

37. Garvey P, Hill C, Fitzgerald G. 1996. The lactococcal plasmid pNP40 encodes a third bacteriophage resistance mechanism, 
one which affects phage DNA penetration. Appl. Environ. Microbiol. 62: 676-679.

38. Collins B, Bebeacua C, Mahony J, Blangy S, Douillard FP, Veesler D, et al. 2013. Structure and functional analysis of the host recognition device of lactococcal phage Tuc2009. J. Virol. 87: 8429-8440.

39. Sing WD, Klaenhammer TR. 1990. Characteristics of phage abortion conferred in lactococci by the conjugal plasmid pTR2030. Microbiology 136: 1807-1815.

40. Ravin V, Räisänen L, Alatossava T. 2002. A conserved C-terminal region in Gp71 of the small isometric-head phage LL-H and ORF474 of the prolate-head phage JCL1032 is implicated in specificity of adsorption of phage to its host, Lactobacillus delbrueckii. J. Bacteriol. 184: 2455-2459.

41. Stockdale SR, Mahony J, Courtin P, Chapot-Chartier M-P, Van Pijkeren J-P, Britton RA, et al. 2013. The lactococcal phages Tuc2009 and TP901-1 incorporate two alternate forms of their tail fiber into their virions for infection specialization. J. Biol. Chem. 288: 5581-5590. 